Research Article

\title{
Social and Environmental Correlates of Obesity in Medical Students of UPUMS Saifai: A Cross- sectional Study
}

\author{
$\underline{\text { Saurabh Saxena }}$, $\underline{\text { Karishma Srivastava }}^{2}, \underline{\text { Somesh Bajpai }}{ }^{3}, \underline{\text { Pooja Pathak }}{ }^{4}, \underline{\text { Prem Prakash Bharti }}{ }^{5}$, \\ Pankaj Kumar Jain ${ }^{6}$ \\ ${ }^{1} \mathrm{MD}, 3,4,5 \mathrm{PG}$ JR, ${ }^{6}$ Professor and Head, Department Community Medicine, Uttar Pradesh University of Medical Sciences, \\ Saifai,Etawah, Uttar Pradesh, India. \\ ${ }^{2}$ Dental Surgeon, Saifai, Etawah, Uttar Pradesh, India. \\ DOI: https://doi.org/10.24321/2455.9199.202107
}

\section{I $\quad \mathbf{N} \quad \mathbf{F}$}

\section{Corresponding Author:}

Pooja Pathak, Department Community Medicine, Uttar Pradesh University of Medical Sciences, Saifai,Etawah, Uttar Pradesh, India.

E-mail Id:

dr.poojapathak673@gmail.com

Orcid Id:

https://orcid.org/0000-0001-5469-9708

How to cite this article:

Saxena S, Srivastava K, Bajpai S, Pathak P, Bharti PP, Jain PK. Social and Environmental Correlates of Obesity in Medical Students of UPUMS Saifai: A Cross-sectional Study. Int J HealthCare Edu \& Med Inform. 2021; 8(1): 8-11.

Date of Submission: 2021-00-oo

Date of Acceptance: 2021-00-00

\section{$\begin{array}{llllllll}\mathbf{A} & \mathbf{B} & \mathbf{S} & \mathbf{T} & \mathbf{R} & \mathbf{A} & \mathbf{C} & \mathbf{T}\end{array}$}

Background: Overweight and obesity are defined as abnormal or excessive fat accumulation that presents a risk to health. Medical students are more prone to gain excess weight due to long study hours and unhealthy food habits.

Aim and Objective: The aim of the study was to find out the prevalence and social and environmental correlates of obesity among undergraduate students of a medical college of a rural area in central Uttar Pradesh, India.

Methodology: A cross-sectional study was conducted in one of the medical colleges of central Uttar Pradesh, India. Data were collected on socio-demographic and behavioural factors, and anthropometric assessments were carried out using standard equipment and procedures.

Results: The proportion of overweight/obesity was $15.6 \%$. Fast food consumption, per capita income and hypertension were found to have statistically significant association with overweight/ obesity.

Keywords: Obesity, Medical Students, Cross-Sectional Study, Social and Environmental Correlates

\section{Introduction}

Overweight and obesity are defined as abnormal or excessive fat accumulation that presents a risk to health. ${ }^{1}$ Obesity is one of the biggest health problems, which is continuously increasing among young adults, especially students. India has been going through a transition from communicable to non-communicable diseases. ${ }^{2}$ Burden of Non communicable diseases are continuously increasing, leading to significant morbidity and mortality among young population. ${ }^{3}$ Rate of obesity is significantly increasing in the young population, due to urbanization of the population and unhealthy food consumption. ${ }^{4}$ One of the reasons for weight gain is being transferred to college life, where students were indulging themselves in various activities and have less time to check on their health status. ${ }^{5}$ Obesity is a predisposing factor for hypertension, which is an important risk factor for the coronary artery disease and stroke. Unhealthy eating patterns and reduced physical activity are 
the important reasons of obesity. ${ }^{6}$ Prevention of obesity is always better than its treatment.

\section{Aim}

To find out Social and environmental correlates of obesity in Medical Students of UPUMS Saifai

\section{Objectives}

- To estimate the prevalence of obesity among medical students of UPUMS Saifai

- To find out socio-demographic variables associated with obesity among study population

\section{Materials and Methods}

- Study Area: UPUMS Saifai, Etawah, Uttar Pradesh

- Study Population: Undergraduate Medical students of UPUMS

- Study Design: Cross sectional study

- Study Period: $1^{\text {st }}$ September 2019 to $1^{\text {st }}$ October 2019

- Sampling Method: Simple random sampling

- Sample Size: The medical university have 150 recognized undergraduate seats per year. MBBS 2016 and 2017 batch were chosen by simple random sampling method. Total 180 students of batch 2016 and 2017 were available at the time of data collection. Rest of the students were absent. So, finally 180 students were considered for data collection

\section{Inclusion Criteria}

- Medical Students studying in UPUMS Saifai Etawah

- Medical students willing to participate in the study

- Medical Students present at the time of data collection

\section{Exclusion Criteria}

- Those who were not willing to participate in the study

\section{Study Tool}

Pre-designed, pre-tested structured questionnaire was used to collect the data from the participants. Height, weight was measured using standard equipment and procedures. Body Mass Index was calculated with the help of these measurements.

\section{Methodology}

A cross-sectional study was done among the undergraduate medical students studying in UPUMS, Saifai, Etawah. The medical university have 150 recognized undergraduate seats per batch. MBBS 2016 and 2017 batch were chosen by simple random sampling method. Total 180 students of batch 2016 and 2017 were available at the time of data collection. Rest of the students were absent. A pre-designed pre-tested structured questionnaire was used to collect information regarding their socio-demographic profile, food habits and the various factors associated with obesity.

\section{Statistical Analysis}

All data was entered into Microsoft Excel worksheet and analyzed using IBM SPSS Software Version 24.0. Tables, Bar diagram and Pie chart were used to present the findings of the study.

\section{Ethical Approval}

Ethical Clearance was taken from Institutional Ethical Committee of UPUMS, Saifai, Etawah, Uttar Pradesh before the start of the study.

\section{Result}

Total 180 medical students including 69 (38.3\%) females and $111(61.7 \%)$ males took part in the study. The proportion of overweight/obesity was $15.6 \%$. Mean BMI for males was $20.99 \pm 1.56$ with range 18.9 to 24.7. For females mean $\mathrm{BMI}$ was $21.56 \pm 2.48$ with range 17.7 to 28 .3. Most of the male and female students were having normal BMI, 87.4\%, 74.9\% respectively (Figure 1 and 2). No student was found to be in obese category. Male students have higher number in the overweight category in comparison with female one, $12.6 \%$ and $11.6 \%$ respectively (Table 1 ). The relationship between overweigh category and hypertension, Veg Diet and non-veg diet and fast-food consumption were found to be significant, $(p$ value $=0.004),(p$ value $=0.02)$ and $(p$ value $=0.048)$ respectively (Table 2 ) .

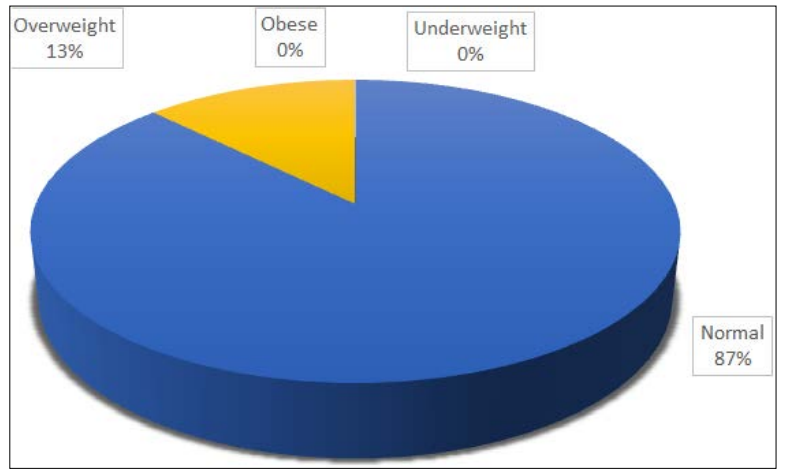

Figure I.Distibution of Male Undergraduate Medical Students according to BMI

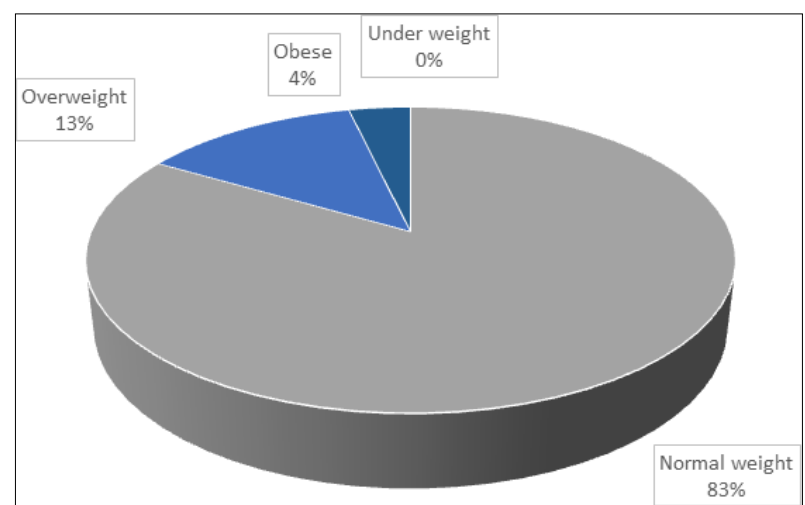

Figure 2.Distibution of Female Undergraduate Medical Students according to BMI 
Table I.BMI of the Study Participants

\begin{tabular}{|c|c|c|c|c|c|}
\hline \multirow[b]{2}{*}{ Sex } & \multicolumn{4}{|c|}{ Observed Body Mass Index of students } & \multirow[b]{2}{*}{ Total } \\
\hline & $\begin{array}{l}\text { Underweight } \\
\left(<18.5 \mathrm{Kg} / \mathrm{m}^{2}\right)\end{array}$ & $\begin{array}{c}\text { Normal weight } \\
\left(18.5-22.9 \mathrm{Kg} / \mathrm{m}^{2}\right)\end{array}$ & $\begin{array}{c}\text { Overweight } \\
\left(23.0-24.9 \mathrm{Kg} / \mathrm{m}^{2}\right)\end{array}$ & $\begin{array}{c}\text { Obese } \\
\left(\geq 25 \mathrm{Kg} / \mathrm{m}^{2}\right)\end{array}$ & \\
\hline Male & $0(0 \%)$ & 97 (87.4\%) & $14(12.6 \%)$ & $0(0 \%)$ & $111(100 \%)$ \\
\hline Female & $4(5.8 \%)$ & $51(74.9 \%)$ & $8(11.6 \%)$ & $6(8.7 \%)$ & 69 (100\%) \\
\hline Total & $4(2.2 \%)$ & $148(82.2 \%)$ & $22(12.2 \%)$ & $6(3.3 \%)$ & $180(100 \%)$ \\
\hline
\end{tabular}

Table 2.Association of Various Correlates with Overweight \& Obesity

\begin{tabular}{|c|c|c|c|c|}
\hline \multirow{2}{*}{ Gender } & \multicolumn{2}{|c|}{ Overweight/ Obesity } & \multirow{2}{*}{ Total } & \multirow{5}{*}{$\begin{array}{c}x^{2}=1.909 \\
p \text { value }=0.205\end{array}$} \\
\hline & Present & Absent & & \\
\hline Male & 97 (87.4\%) & $14(12.6 \%)$ & $111(100 \%)$ & \\
\hline Female & 55 (79.7\%) & $14(20.3 \%)$ & 69 (100\%) & \\
\hline Total & $152(84.4 \%)$ & $28(15.6 \%)$ & $180(100 \%)$ & \\
\hline \multicolumn{4}{|c|}{ Current Smoking Habit } & \multirow{4}{*}{$\begin{array}{c}x^{2}=1.43 \\
p \text { value }=0.379\end{array}$} \\
\hline Present & $24(92.3 \%)$ & $2(7.7 \%)$ & $26(100 \%)$ & \\
\hline Absent & $128(83.1 \%)$ & $26(16.9 \%)$ & $154(100 \%)$ & \\
\hline Total & $152(84.4 \%)$ & $28(15.6 \%)$ & $180(100 \%)$ & \\
\hline \multicolumn{4}{|c|}{ Adequate physical activities } & \multirow{4}{*}{$\begin{array}{c}x^{2}=2.3 \\
p \text { value }=0.146\end{array}$} \\
\hline Present & $94(87.9 \%)$ & $13(12.1 \%)$ & $107(100 \%)$ & \\
\hline Absent & $58(79.5 \%)$ & $15(20.5 \%)$ & $73(100 \%)$ & \\
\hline Total & $152(84.4 \%)$ & $28(15.6 \%)$ & $180(100 \%)$ & \\
\hline \multicolumn{4}{|c|}{ Hypertension } & \multirow{4}{*}{$\begin{array}{c}x^{2}=8.404 \\
p \text { value }=0.004\end{array}$} \\
\hline Present & $17(65.4 \%)$ & $9(34.6 \%)$ & $26(100 \%)$ & \\
\hline Absent & $135(87.7 \%)$ & $19(12.3 \%)$ & $154(100 \%)$ & \\
\hline Total & $152(84.4 \%)$ & $28(15.6 \%)$ & $180(100 \%)$ & \\
\hline \multicolumn{4}{|c|}{ Diet } & \multirow{4}{*}{$\begin{array}{c}x^{2}=5.414 \\
p \text { value }=0.02\end{array}$} \\
\hline Vegetarian & $56(93.3 \%)$ & $4(6.7 \%)$ & $60(100 \%)$ & \\
\hline Non-Vegetarian & $96(80 \%)$ & $24(20 \%)$ & $120(100 \%)$ & \\
\hline Total & $152(84.4 \%)$ & $28(15.6 \%)$ & $180(100 \%)$ & \\
\hline \multicolumn{4}{|c|}{ Fast Food Consumption } & \multirow{4}{*}{$\begin{array}{c}x^{2}=3.906 \\
p \text { value }=0.048\end{array}$} \\
\hline Present & $135(86.5 \%)$ & $21(13.5 \%)$ & $156(100 \%)$ & \\
\hline Absent & $17(70.8 \%)$ & $7(29.2 \%)$ & $24(100 \%)$ & \\
\hline Total & $152(84.4 \%)$ & $28(15.6 \%)$ & $180(100 \%)$ & \\
\hline
\end{tabular}

\section{Discussion}

Aslani A et $\mathrm{l}^{5}$ (2020) conducted a study on medical students and found that the prevalence of obesity and overweight was $3.2 \%$ and $25.3 \%$, respectively. There was a positive and significant statistical association between emotional eating $(r=.542)$, extrinsic eating $(r=.488)$ and perceived stress ( $r=.489$ ) with BMI, also significant and an inverse association was obtained between emotional eating $(r=-.488)$ and total physical activity score $(r=-.394)$ with BMI.

Odlaug B.L. et $\mathrm{al}^{7}$ (2015) found in a study that total of 492 $(27.9 \%)$ students were overweight $(20.2 \%$; range 25.01 29.98) or obese (7.7\%; range 30.04-71.26). Overweight and obesity were associated with significantly lower overall academic achievement, more depressive symptoms, and using diet pills for weight loss. 
Fernandez et $\mathrm{al}^{8}$ (2014) conducted similar study with title "Study regarding overweight/obesity among medical students of a teaching hospital in Pune, India" on medical students of D.Y. Patil Medical College and found that Total 159 students including 66 (41.5\%) female and 93 (58.5\%) males took part in the study. The proportion of overweight/ obesity was $13.2 \%$ (C.I.: 7.84 - 18.5\%). Daily calorie intake, lack of daily physical activity, daily consumption of Tea/ Coffee/Fruit juices, playing outdoor games, socio-economic status, and family history of obesity were found to have statistically significant association with overweight/obesity.

Gupta et $\mathrm{al}^{9}$ (2009) did a study on undergraduate medical students of Midnapore Medical College, Paschim Medinipur, India and found that out of that total students $(\mathrm{N}=114)$, $70(61 \%)$ were male and 44 (39\%) were female. Out of male students, 11 and 4 students were found in the overweight and the obese category, respectively. Whereas out of female students, 9 were found to be in the overweight category and no students were found in the obese category. The prevalence of overweight was calculated to be $17.5 \%$, prevalence of obesity was $3.4 \%$, overall.

\section{Conclusion}

Prevalence of overweight/ obesity in undergraduate medical students is high. Strong obesity surveillance programs addressing the social, environmental and lifestyle correlates are needed. Higher educational institutions should be aware of the significant burden associated with overweight and obesity in students, and of the differing demographic and clinical associations between overweight or obesity in men and women.

\section{Sources of Funding: None \\ Conflicts of Interest: None \\ References}

1. WHO [Internet]. Obesity [cited 2021 July 28]. Available from: https://www.who.int/health-topics/ obesity\#tab=tab_1.

2. Kumar S, Kaushik A. Non-communicable diseases: A challenge. Indian Journal of Community Health. 2012 Dec 31;24(4):252-4. [Google Scholar]

3. Peltzer K, Pengpid S, Samuels T, Özcan NK, Mantilla C, Rahamefy $\mathrm{OH}$, Wong ML, Gasparishvili A. Prevalence of overweight/obesity and its associated factors among university students from 22 countries. International Journal of environmental research and public health. 2014 Jul;11(7):7425-41. [Pubmed] [Google Scholar]

4. Balhareth A, Jafer M, Borgh-Sleddens EV, Kremers S, Meertens R. Determinants of weight-related behaviors in male saudi university students: a qualitative approach using focus group discussions. Int J Environ Res Pub Health. 2021 Jan;18(7):3697. [Pubmed] [Google Scholar].
5. Aslani A, Faraji A, Allahverdizadeh B, Fathnezhad-Kazemi A. Prevalence of obesity and association between body mass index and different aspects of lifestyle in medical sciences students: A cross-sectional study. Nursing Open. 2021:Jan;8(1):372-9. [Pubmed] [Google Scholar]

6. WHO [Internet]. Overweight and obesity: WHO factsheet [cited 2011 July 21]. Available from https:// www.who.int/news-room/fact-sheets/detail/obesityand-overweight.

7. Odlaug BL, Lust K, Wimmelmann CL, Chamberlain SR, Mortensen EL, Derbyshire K, Christenson G, Grant JE. Prevalence and correlates of being overweight or obese in college. Psychiatry Res. 2015 May 30;227(1):58-64. [Pubmed] [Google Scholar]

8. Fernandez K, Singru SA, Kshirsagar M, Pathan Y. Study regarding overweight/obesity among medical students of a teaching hospital in Pune, India. Med J DY Patil Univ. 2014;7:279-83. [Google Scholar]

9. Gupta S, Ray TG, Saha I. Overweight, obesity and influence of stress on body weight among undergraduate medical students. Ind J Community med. 2009 Jul:34(3);255-7. [Pubmed] [Google Scholar] 